emont Graduate School, Office of the President, 160 East 10th Street, Claremont, CA 91711.

Adapted from The Claremont Graduate School News

\section{Gerhart Niemeyer}

Gerhart Niemeyer, emeritus professor of government and international studies at the University of Notre Dame passed away June 23, 1997.

Niemeyer was born in Essen, Germany, on February 15, 1907. He studied political science at Cambridge and the German Universities of Munich and Kiel. He received a law degree from the University of Kiel in 1932 before leaving Germany during the early years of Hitler's regime. He lived for a time in Spain before emigrating to the United States, where he joined the faculty of Princeton University in 1937. In 1941 he published a widely praised book, Law Without Force, which rapidly became required reading for students of international law.

The U.S. State Department appointed Niemeyer to the planning staff of its Bureau of United Nations Affairs in 1950, and after three years in that post, he became an analyst for the Council on Foreign Relations. He joined the Notre Dame faculty in 1955 .

At Notre Dame, Niemeyer taught introductory courses on political theory as well as two popular courses, "Modern Political Ideologies," and "The Reconstruction of Political Theory." He also wrote numerous articles in scholarly and popular journals on a variety of topics including cultural history, the New Left, education, and the writings of Eric Voeglin and Alexander Solzhenitsyn. In 1972, when the editor of Notre Dame Magazine invited several faculty members to write their own epitaphs, Niemeyer's cryptic submission read, "Brief span the Gift, Cool bed the dot. Struggle for the lot. Look for the Lift."

Michael O. Garvy

University of Notre Dame

\section{Sam Nolutshungu}

Sam C. Nolutshungu, professor of political science and African politics at the University of Rochester, died of cancer on August 12, 1997.

Professor Nolutshungu was an internationally acclaimed expert on South African politics. "He was a world-class scholar, a gifted teacher, and a vital intellectual force in the department, the College, and the broader intellectual community," said Harold W. Stanley, chair of the University's department of political science. "He combined these considerable talents with great warmth, grace, and kindness."

In December 1996, Nolutshungu was selected to be the next vice chancellor at the University of the Witwatersrand in Johannesburg, South Africa, considered one of the most powerful and prestigious academic positions in that country. But in January he declined the post for health reasons.

As a university student, Sam Nolutshungu left his homeland because of apartheid policies and went into exile in England, where he stayed to earn his doctorate and become a university faculty member. In a newspaper article last year, he told a reporter: "There is a great sense of satisfaction in seeing the ideas we espoused then becoming the foundation for the new South Africa."

Before his arrival in Rochester, Nolutshungu served on the faculty of the University of Manchester where he was Tutor to the Honours School of Politics and Modern History. He also held positions on the faculties of the University of Lancaster, the University of Ibadan, York University in Toronto, and Dartmouth College, and he was a visiting research fellow at Yale University.

Nolutshungu came to the University of Rochester in 1991 as a tenured professor in the political science department. He also held a joint appointment in the University's Frederick Douglass Institute for Af- rican and African-American Studies and served as the Institute's acting director from 1995 to 1997.

In his academic career, Professor Nolutshungu had specialized in international politics with an emphasis on the politics of South Africa. He had written five books and numerous articles on Africa. His doctoral thesis at the University of Manchester published in 1975 South Africa in Africa: A Study of Ideology and Foreign Policy, is considered to be the first major study of South African politics by a black South African.

Earlier this year, Nolutshungu told colleagues that he decided to apply for the top administrative position at Witwatersrand "because I saw in it a brilliant opportunity to render service to my country. I believed that my experience of university education in different countries and continents would be of value to Witwatersrand and South Africa. I was convinced that the academic work I had pursued for a quarter of a century into the problems of South Africa and the African continent would reinforce that contribution."

Professor Nolutshungu was an active member of the international political science community as reflected in his membership on the Social Science Research Council Committee on International Peace and Security. In recent years, his research and teaching focused on the transformation of the apartheid state in South Africa. In particular, he was exploring the relationships between democratized politics, a constitutional commitment to non-racism, and reforms to reduce racialized economic inequality.

He is survived by his wife Veli and two daughters, Nomvuyo and Nomalungelo and a brother, Peter.

\section{Sharon Dickman}

University of Rochester 